\title{
The use of grinded andesite-sand and foaming- agent to improve the porosity of foam-concrete
}

\author{
Rommel Erwin ${ }^{1, *}$, Rusdianto Yunan ${ }^{1}$, Dawara Kiki Ruris ${ }^{2}$, Eddy $\mathrm{S} \mathrm{Tri}^{3}$ \\ ${ }^{1} \mathrm{CE}$ Department, University of Muhammadiyah Malang, Malang, Indonesia \\ ${ }^{2}$ Post-graduate, CE Department, University of Muhammadiyah Malang, Malang, Indonesia \\ ${ }^{3}$ Senior Manager Research \& Development PT. Semen Indonesia, Gresik, Indonesia
}

\begin{abstract}
There has been an increase in the demand for the use of green concrete in construction. Foam concrete is a lightweight concrete type that has the characteristics of being lightweight, low-strength, highly porous with a high absorption rate and with good insulation properties. The use of sand smoothed andesite in the manufacture of foam concrete is expected to improve the properties of porous concrete and make it more suitable for use. In this study, 120 mortar cubes with the size of $5 \mathrm{~cm}$ was used for the density testing, compressive strength testing and porosity testing of foam concrete. Foam concrete is made by mixing cement, sand andesite of $1: 2.75$ and w/c 0.7 and a foaming agent, which are respectively $1 \%, 2 \%$, $3 \%$, and $4 \%$. Porosity measurements with the soaking method and the concrete compressive strength test were performed, respectively at the age of $7,14,21$, and 28 days. The results showed that the increase in use of a foaming agent will cause a reduction in the density and the compressive strength of the concrete. While the porosity of foam concrete which is measured at the "volume of permeable void" will increase with the decreasing density and compressive strength of concrete.
\end{abstract}

\section{Introduction}

Foamed concrete is produced by injecting preformed stable foam or by adding a special airentraining admixture known as a foaming agent into a base mixture of cement paste or mortar (cement + sand + water or cement + water) [1-3]. The primary factor that influences the manufacturing of good quality concrete is through the addition of foam-agent in order to create more bubbles in the cement mortar. The amount of air bubbles which are generated would be very influential on the physical properties of the foam concrete such as the density, porosity, and the air void of the foam concrete. Foam concrete has some advantages compared with regular concrete which makes it more beneficial for use. It has the benefits of being lightweight, with good insulating properties, fire resistant, as well as being environmentally friendly. However, some disadvantages of foam concrete are a high shrinkage, large pores and a high permeability. Some applications of foam concrete include light brick, wall panels, ornament buildings, cladding material, the filler on the concrete ready-mix etc.

* Corresponding author: erwin_r@umm.ac.id 
Andesite is a type of magma that erupts explosively because it tends to have high gas content [4]. It is viscous, and therefore it traps gas, builds pressure and explosively erupts. High viscosity is related to high silica content. The andesite sand is derived from volcanic erosion processes that are encountered in the flow of the river at the foot of the volcano. The andesite sand has silica content $\left(\mathrm{SiO}_{2}\right)$ that ranges from $57-63 \%$. Usage of aggregate andesite-sand for the foam concrete is expected to resolve the porosity weaknesses of foam concrete. The effect of adding a foaming agent in foamed concrete will produce air bubbles into the mortar. This is far better than the foamed concrete having the properties of porous concrete.

Like all cement products, foam concrete shrinks during the setting stage. The shrinkage depends upon the type and amount of cement in the mix, water-to-cement ratio, type of curing process, size of element, quantity of sand and the density of foamed concrete. The most percentage of shrinkage occurs during the first 28 days, after and soundproofing screeds in multi-story residential and commercial buildings. Concrete within this density range is also suitable for bulk-fill applications [5].

Research was conducted on the influence of the addition of aluminum powder on aerated concrete. The research was done to discover how aluminum powder will affect the density, porosity, and the absorptivity of aerated concrete. The addition of aluminum powder on aerated concrete can reduce the porosity and the density of the form size. The porosity increases as the aluminum powder content increases. The lowest porosities of $8.85 \%$ and $2.49 \%$ were obtained for the control $(0 \% \mathrm{Al})$ by soaking in water and vacuum saturated methods respectively [6].

The use of porous aggregate material called expanded glass (EG) granules on foam concrete has been done by using the mineral mixture of pozzolan metakaolin (MK) and microsilica (MS) to improve the properties of foam concrete shrinkage and long-term durability [7].

Porous concrete occurs when trapped air exists in the cavities during the decomposition of mineral aggregate. The mineral aggregate which occupies $70-75 \%$ portions of the volume of the concrete will significantly affect the porosity of concrete. Therefore, the gradation of aggregate grains also affects the porosity of concrete whereby a uniform fine grain size will reduce the porosity of concrete. This is because the small grains can occupy the pores between the larger grains so that the porosity of the concrete becomes small. The concrete porosity can be calculated by with the following equations [8]:

$$
\begin{aligned}
& \text { Volume of permeable void }=\left[\frac{(g 2-g 1)}{g^{2}}\right] \times 100 \% \\
& \text { Total void volume }=\left[\frac{(g 3-g 1)}{g^{3}}\right] \times 100 \%
\end{aligned}
$$

$g_{1} g_{2} g_{3}$, respectively bulk density; apparent density; absolute density (g/cc)

The use of sand with grain fineness of less than $2.36 \mathrm{~mm}$ has also been done with the manufacture of foam concrete by using the foaming agent and testing the properties of the foam concrete porosity through several methods, among others; the soaking method, the saturated vacuum method and the method of mercury intrusion porosimetry (MIP) in which the retrieved value of porosity varies [9].

This study differs from other research that has been conducted on foam concrete research. There is a difference in the combination of andesite-sand grinded, and the amount of foam-agent used in the manufacture of foam concrete. This study aims to determine the effect of the use of andesite-sand grinded and foam-agent on the porosity property of foam concrete. 


\section{Materials and mix-proportions}

The research was conducted at the Laboratory of PT Semen Indonesia, Gresik, East Java, Indonesia. Pre-studies were performed on a mortar consistency test with several variations of $\mathrm{w} / \mathrm{c}$ ratio and foaming agent. Figure 1 illustrates that the addition of the foaming agent with fixed w/c ratio of 0:70 causes the workability of the foam concrete to be lower. The consistency of foam concrete decreased up to $73.3 \%$ with the use of $4 \%$ foaming agent.

The foam concrete mix consists of; cement, sand, water of 1: 2.75: 0.7 with the use of paste foam (fa/w ratio of $1: 20)$ respectively at $0 \%, 1 \%, 2 \%, 3 \%$ and $4 \%$. The foaming agent used was the TXP ACC synthesis type. The Andesite sand used was milled until it reached the following specifications; $80 \%$ passing sieve No. 100 and $53.2 \%$ retained on the sieve No. 200; density $2.9 \mathrm{~g} / \mathrm{cm}^{3}$; absorption $4.5 \%$.

The test object is made of a 120 mortar cubes with the size of $5 \mathrm{~cm}$, respectively for testing the density, compressive strength and porosity of the concrete at the age of $7,14,21$, and 28 days. The porosity measurement with the soaking method is termed water absorption. In this context, a capillary suction measurement is suggested.

Table 1. Mixed concrete foam.

\begin{tabular}{|c|c|c|c|c|c|}
\hline \multirow{2}{*}{ Material } & Mix- & \multicolumn{4}{|c|}{ Mix-proportion } \\
\cline { 3 - 6 } & controls & I & II & III & IV \\
\hline cement & 1 & 1 & 1 & 1 & 1 \\
\hline andesite sand & 2.75 & 2.75 & 2.75 & 2.75 & 2.75 \\
\hline water-cement (w/c) ratio & 0.7 & 0.7 & 0.7 & 0.7 & 0.7 \\
\hline foam-agent / cement (\%) & 0 & 1 & 2 & 3 & 4 \\
\hline number of specimens & 24 & 24 & 24 & 24 & 24 \\
\hline
\end{tabular}

\section{Result and discussion}

\subsection{Workability of concrete}

Workability of concrete is a measure of the ease at which concrete work can be performed in the field or on site. The measurement of workability includes how easy the concrete is to carry and place, how easy it is to work, how easy it is to compact, and how easy it is to finish. The level of workability obtained in this study can be seen in Figure 1 below. The workability of foam concrete with w/c 0.70 and the use of foaming agent $0 \%$ and $1 \%$ are still included in the permissible requirements.

According to previous studies [10], it was explained that the foam concrete with more than 0.6 fas will increase the workability of concrete. Foam concrete can absorb water so as to increase the volume of fresh concrete. The workability of foam concrete is not the same as normal concrete. 


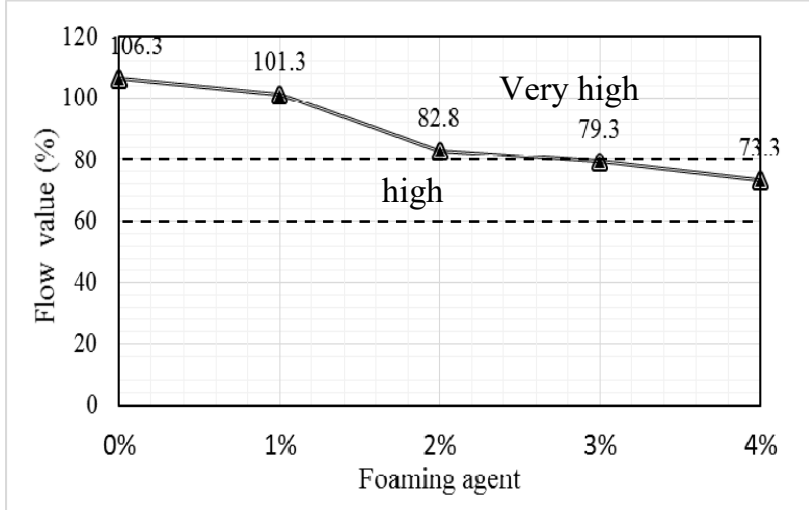

Fig. 1. Workability of foam concrete.

The result from the figure shows that the consistency value of good stability foam concrete is $45 \%$, or the level of workability in the medium class is $40 \%-60 \%$. From the results of the flow table test in this study, the use of a foaming agent $0 \%, 1 \%, 2 \%$ are in very high class that is between $80-120 \%$. While for foaming agent $3 \%$ and $4 \%$ are in high class which is $60 \%$ to $80 \%$.

Table 2. The level of foam concrete workability [10].

\begin{tabular}{|c|c|c|}
\hline $\begin{array}{c}\text { Class } \\
\text { Designation }\end{array}$ & Flow Values & Description \\
\hline VL & $0-20 \%$ & Very low \\
\hline L & $20-40 \%$ & Low \\
\hline M & $40-60 \%$ & Medium \\
\hline H & $60-80 \%$ & High \\
\hline VH & $80-120 \%$ & Very High \\
\hline
\end{tabular}

\subsection{Density of concrete}

The density of foam concrete influences the amount of foaming agent used. The more foam-agent that is used, the more porous the concrete will be. This is because the pores will contain more trapped air. The usage of foaming agent until $4 \%$ of the cement weight is foam-agent produces a concrete density of $1,533 \mathrm{~kg} / \mathrm{m}^{3}$. The use of foam-agent until $2 \%$ of the cement weight is foam-agent produces lightweight concrete due to the density of 1,867 $\mathrm{kg} / \mathrm{m}^{3}$ or a decrease of $22 \%$ less than mortar concrete. The foam concrete density values range from $400-1,600 \mathrm{~kg} / \mathrm{m}^{3}$ [10]. Cemex Ready Mix, which is one of the ready-mix companies in Mexico classifies foam concrete produced based on its density value, including the Highly Air-Entrained Concrete (HAC) type which has a density of 1,600 $2,000 \mathrm{~kg} / \mathrm{m}^{3}$. Whereas according to SNI $03-2847-2002$, the density of lightweight concrete is not more than $1,900 \mathrm{~kg} / \mathrm{m}^{3}$.

\subsection{Strength of concrete}

The results of strength concrete testing of the foaming agent for some of the concrete can be seen in Figure 2. The strength concrete decreases with the use of more than low quantity agent foam. The use of the foaming agent up to $2 \%$ on curing for 14 days causes the compressive strength of the concrete to incline above $10 \mathrm{MPa}$ (the requirement for the use of wall grade-I in buildings according to SNI 03-0349-1989), i.e. 12.49 MPa. The trend of 
increasing the compressive strength of foam concrete by increasing the number of curing time up to 28 days is significant in the use of $1 \%$ and $2 \%$ foaming agent. While the use of $3 \%$ and $4 \%$ foaming agent in the cement hydration process for up to 28 days did not significantly increase the compressive strength.

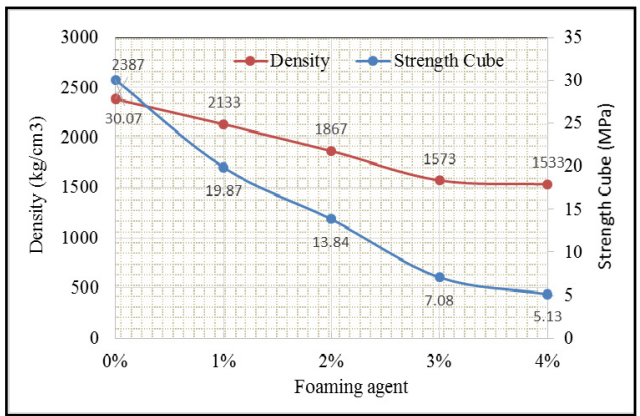

Fig. 2. Strength and curing time each of foam agent.

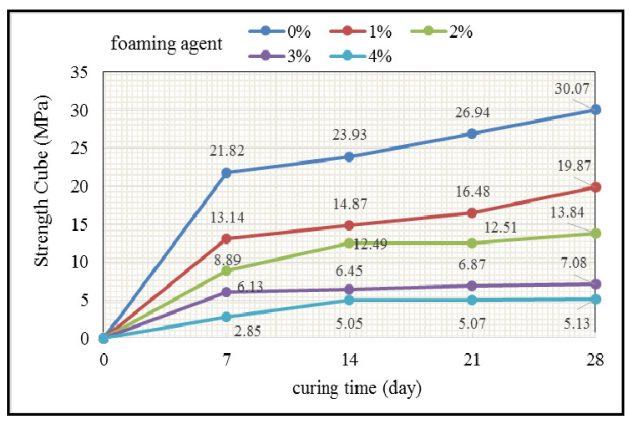

Fig. 3. Curve strength, density of concrete each foam agent.

Figure 3 shows that the concrete density factor significantly affects the strength of the concrete. The use of finer aggregate materials can increase the density of foam concrete, but the excessive use of aggregates (especially sand) also results in the increased shrinkage of concrete. Figure 3 also illustrates that the use of $1 \%$ and $2 \%$ foaming agent can produce foam concrete strength that is above $10 \mathrm{MPa}$, but it remains high-density concrete. The use of $3 \%$ and $4 \%$ foaming agent to achieve a relatively low density, but also low concrete strength, so it can only be used in non-structural part is effective.

Research with the use of unprocessed-slag aggregate $30 \%$, and the addition of $1 \%$ of superplasticizer while the foaming agent ratio is 1:30 on foam concrete with a mixture of 1 : 2: 0.45 generate density $1300 \mathrm{~kg} / \mathrm{m}^{3}$. When the use of the cement was reduced to less than $300 \mathrm{~kg} / \mathrm{m}^{3}$, compressive strength on 28 days increased by $32 \%$ (8 MPa), splitting tensile strength increased $46.5 \%(1.224 \mathrm{MPa})$, and flexural strength increased by $61 \%(2.4 \mathrm{MPa})$ compared to foam concrete without aggregate unprocessed-slag [11].

Table 3. Characteristic of foam concrete.

\begin{tabular}{|c|c|c|c|c|c|c|c|c|c|c|c|c|c|}
\hline \multirow{2}{*}{$\begin{array}{c}\text { Foaming } \\
\text { agent }\end{array}$} & \multirow{2}{*}{$\begin{array}{c}\text { Density } \\
\left(\mathbf{k g} / \mathbf{m}^{\mathbf{3}}\right)\end{array}$} & \multicolumn{3}{|c|}{$\begin{array}{c}\text { Volume of permeable } \\
\text { voids (\%), curing } \\
\text { (day) }\end{array}$} & \multicolumn{3}{|c|}{$\begin{array}{c}\text { Total volume voids } \\
\text { (\%), curing (day) }\end{array}$} & \multicolumn{5}{|c|}{$\begin{array}{c}\text { Strength (MPa), } \\
\text { curing (day) }\end{array}$} \\
\cline { 3 - 15 } & & $\mathbf{7}$ & $\mathbf{1 4}$ & $\mathbf{2 1}$ & $\mathbf{2 8}$ & $\mathbf{7}$ & $\mathbf{1 4}$ & $\mathbf{2 1}$ & $\mathbf{2 8}$ & $\mathbf{7}$ & $\mathbf{1 4}$ & $\mathbf{2 1}$ & $\mathbf{2 8}$ \\
\hline $0 \%$ & 2387 & 13 & 21 & 12 & 12 & 15 & 21 & 18 & 16 & 21.82 & 23.93 & 26.94 & 30.07 \\
\hline $1 \%$ & 2133 & 17 & 25 & 15 & 14 & 15 & 21 & 17 & 16 & 13.14 & 14.87 & 16.48 & 19.87 \\
\hline $2 \%$ & 1867 & 21 & 31 & 14 & 17 & 14 & 17 & 14 & 15 & 8.89 & 12.49 & 12.51 & 13.84 \\
\hline $3 \%$ & 1573 & 37 & 43 & 41 & 30 & 8 & 18 & 16 & 13 & 6.13 & 6.45 & 6.87 & 7.08 \\
\hline $4 \%$ & 1533 & 48 & 46 & 52 & 45 & 17 & 18 & 24 & 22 & 2.85 & 5.05 & 5.07 & 5.13 \\
\hline
\end{tabular}

\subsection{Porosity of concrete}

Porosity is the sum of the entrained air pores and voids within the paste. The process of gas release on the manufacture of foam concrete can affect the microstructure. The character of the foamed concrete material structure is known to be the matrix of solid micropores and 
macropores. Macropores are formed due to the mass expansion caused by aeration and micropores. It will appear between the partition of the macropores.
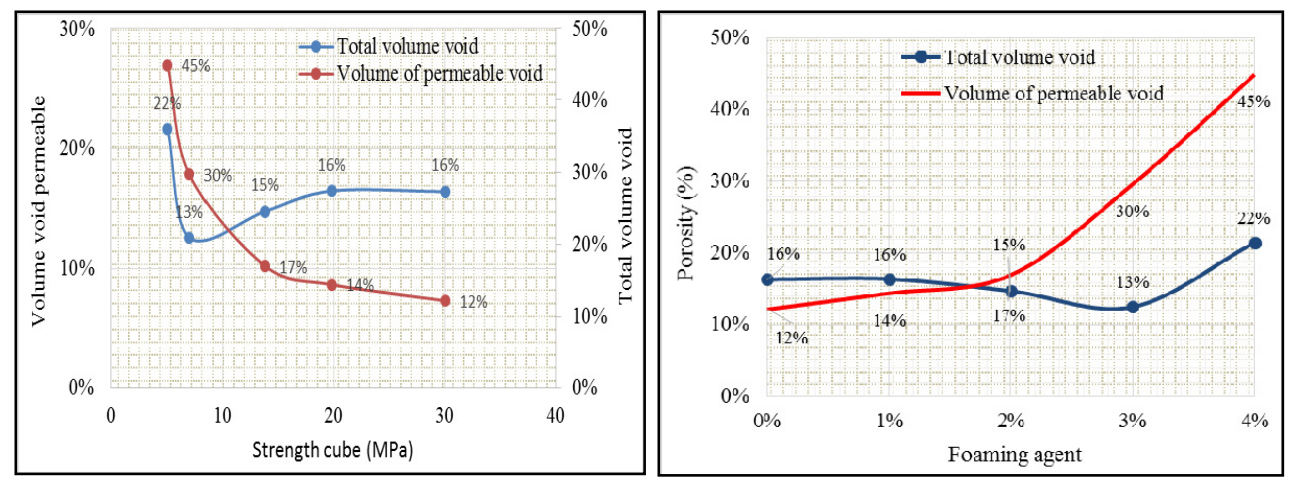

Fig. 4. Porosity and foam agent of foam concrete. Fig. 5. Porosity and strength cube of foam concrete.

The porosity in foam concrete is different from that of regular concrete. The cavities formed on foam concrete are not only influenced by the presence of the air trapped during the hydration process. There are also cavities that are formed due to the surfactant reaction that occurs during the mixing of the foaming agent in concrete. The bubbles formed contain water so that the air-water interface is stable after the concrete hydration process is complete. The cavities formed on the foam concrete are divided into two. The cavities include filled water cavities that are capillary and unstable, or the water in the cavities that can come out if there is pressure both due to the load and temperature, while the other side there is also a cavity, or a stable cavity formed by a surfactant reaction process in which water will not come out so long as the cavity lining is still stable. Thus, the porosity of foam concrete measured by the volume of air cavities in concrete that can be bypassed by the water or volume of a permeable void, or it could be measured by the total volume void of the cavity that contains water and air in the foam concrete. The total volume of the void formed by the surfactant reaction depends on the amount of foaming agent that is used in the manufacture of the foam concrete. The use of fine aggregate "ground Andesite sand" also affects the porosity and the cavity of the foam concrete.

The results of the research conducted [7] shows that the use of lightweight aggregates and porous "expanded glass granules (EG)" in the preparation process of foam concrete samples, can reduce the density of foam concrete samples by $54 \%$ (in comparison to the samples of the reference mixture). With the reduction of density and an increase in porosity, these samples showed about 33\% lower values of compression strength (after 28 days of hardening) than the samples made from the reference mixture.

Figure 5 illustrates the relationship between the porosity and the compressive strength of foam concrete, where the compressive strength decreases, and the volume of permeable void increases for the foam concrete. While figure 4 shows the effect of the addition of a foaming agent to the largest porosity value of foam concrete, whereby for up to $4 \%$ foaming agent used, the foam concrete has total void volume of $22 \%$ and the volume of the permeable void is $45 \%$, at 28 days. With the use of $1 \%$ and $2 \%$ foaming agent, the best total void volume value was obtained, each of $16 \%$ and $15 \%$ with a compressive strength of 19.87 $\mathrm{MPa}$ and $13.84 \mathrm{MPa}$ at the age of 28 days. Likewise, the volume of permeable voids produced respectively at $14 \%$ and $17 \%$ when the agent foam used was $1 \%$ and $2 \%$ respectively. 


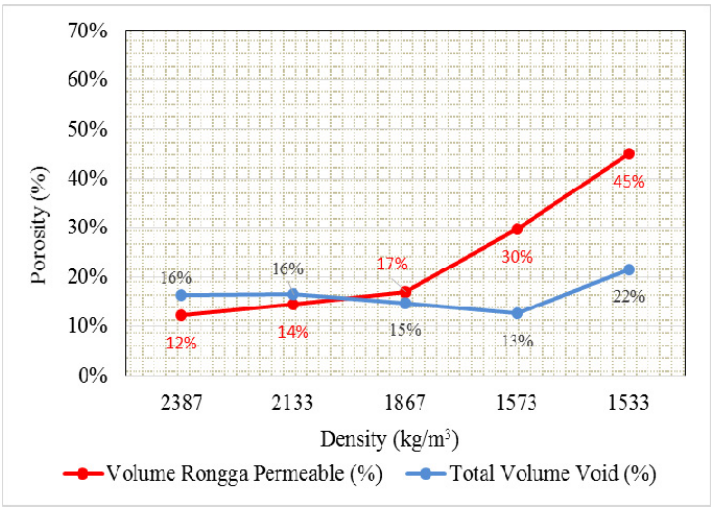

Fig. 6. Density and porosity curve, curing time 28 day.

Porosity also affects the density of foam concrete. Figure 6 shows that an increase in the porosity of the concrete causes the concrete density to be lower. Porosity, when measured by total void volume of $13 \%$, has the lowest density value of $1573 \mathrm{~kg} / \mathrm{m} 3$ with the use of $3 \%$ foaming agent. While the porosity which is measured from the volumes of permeable void tends to increase along with the addition of the foaming agent. At a concrete density of $45 \%$, the porosity has a value of $1533 \mathrm{~kg} / \mathrm{m} 3$. The addition of the foaming agent will lead to a decrease in the density of foam concrete. The density of concrete that was categorized as lightweight concrete was obtained by adding $2 \%, 3 \%$ and $4 \%$ foaming agent with each volume of permeable void value of $17 \%, 30 \%$, and $45 \%$, while the total void volume was $15 \%, 13 \%$, and $22 \%$.

The results of this study are almost identical to the results of other research that has been done previously by other researchers [9] where the increase in porosity of foam concrete is always followed by a decrease in density. In this research, it is also explained that the increase in porosity is not followed by an absorption of water, because the artificial pores of the foam do not absorb water and are not-inter connected between each other pores. The porosity of the foam concrete decreases from $51 \%$ at $1135 \mathrm{~kg} / \mathrm{m}^{3}$ density to $29 \%$ at $1790 \mathrm{~kg} / \mathrm{m}^{3}$ density with the use of the foaming agent at 0.35 and 0.13 respectively.

\section{Conclusion}

The amount of foam-agent used in the making of foam concrete greatly affects the workability, density, compressive strength, and porosity of the concrete. The porosity increases along with the reduced density and the compressive strength of the foam concrete. The usage of grinded andesite-sand and $2 \%$ foam-agent on the foam concrete will increase the density and the compressive strength of foam concrete, respectively at $1867 \mathrm{~kg} / \mathrm{m}^{3}$ and $13,84 \mathrm{MPa}$, while the use of $2 \%$ foam-agent to obtain $15 \%$ and $17 \%$ best porosity value, respectively for the total void volume and volume of permeable void.

The author to thanks DRPM Kemenristekdikti who have funded this research in the fiscal year 2017-2018

\section{References}

1. D. Paul, Autoclaved Aerated Concrete, (2013)

2. A. J. Hamad, Int'l. J. Material Sci. and Eng, 2, 152-157 (2014) 
3. M. D. Jalal, A. Tanveer, K. Jagdeesh, F. Ahmed, Int'l. J. Civil Eng. Research, 8, 1-14 (2017)

4. G. A. Smith, J. E. Lotosky, J. Sed Research, A.65, 91-98 (1995)

5. T. H. Maheshkumar, Int'l J. Civil Str, 4, 145-158 (2014)

6. R. Shabbar, P. Nedwell, M. Wilson, Z. Wu, $2^{\text {nd }}$ Int'l. Conference on Architecture, Structure and Civil Engineering (Scopus/ISI Thomson, 2016)

7. E. Namsone, G. Sahmenko, A. Korjakins, E. Namsone, Const. Sci, 19, 13-20 (2016)

8. ASTM C642-06, ASTM International (2006)

9. A. A. Hilal, N. H. Tom, A. A. Dawson, J Adv. Conc. Tech, 12, 535-544 (2014)

10. K. E. K. Nambiar, K. Ramamurthy, J. Material in Civil Eng, 20, 111-117 (2008)

11. H. Awang, J. Aljoumaily, N. Noordin, M. Al-Mulali, Building Surveying, Facilities Management and Engineering Conference (EDP Science, 2014) 